\title{
Exilio y trauma en la memoria de César L. Romero (República Dominicana) $^{1}$
}

\author{
Walter Bonilla Carlo
}

Resumen: Romero, exiliado antitrujillista desde 1937 hasta 1961, narra la pérdida dolorosa y traumática de su espacio geográfico, las dificultades emocionales y económicas de la adaptación a un nuevo territorio y las angustias personales de volver a su país. A través de Del duro exilio el autor revela las profundas huellas o heridas de un destierro político que constituye las características más sentidas y repetidas de su memoria.

Palabras clave: Memoria - Exilio - Trauma - República Dominicana - Rafael L. Trujillo
Abstract: Romero, an anti-Trujillo exile from 1937 to 1961, narrates the painful and traumatic loss of his geographical space, the emotional and economic difficulties of adapting to a new territory and the personal anxieties of returning to his country. Through Del duro exilio the author reveals the deep traces or wounds of a political exile that constitutes the most felt and repeated characteristics of his memory.

Keywords: Memory - Exile - Trauma Dominican Republic - Rafael L. Trujillo

\section{Las etapas traumáticas del exilio}

La memoria traumática, más que cualquier otra, conmina al lenguaje a hacer de su delirio una composición, a dar vida a nuevas narraciones.

Guadalupe Santa Cruz, «Capitales del olvido», en Políticas y estéticas de la memoria (Chile, 2000).

Es frecuente encontrar en las investigaciones del exilio iberoamericano una serie de preocupaciones en torno a la forma de analizar la diversidad de experiencias, tanto individuales como colectivas, de seres

\footnotetext{
${ }^{1}$ Trabajo recibido el 06/08/2017. Aceptado el 11/12/2017.

${ }^{2}$ Bachiller en Historia por la Universidad Interamericana, Recinto de San Germán, Puerto Rico. Magister en Artes y Doctor en Filosofía y Letras en la Universidad de Puerto Rico, Recinto de Río Piedras. Contacto: wabonilla@hotmail.com
} 
humanos que salieron forzosamente de sus respectivos países durante el siglo XX. ${ }^{3}$ Aunque en la República Dominicana el exilio no fue masivo como ocurrió en España, Chile y Argentina, no deja de representar un reto el reflexionar sobre las imágenes de dolor y de sufrimiento de cada uno de los exiliados. Las heridas del exilio no son iguales para todos los afectados, ya que la memoria está sujeta al mundo personal y social que antes se ocupaba en la sociedad, sintiéndose el expulsado perdido en su nuevo entorno (Guinsberg, 2005, pp.161-180). En el destierro, el exiliado descubre que las estructuras sociales y políticas son diferentes, se convierte en un desconocido para los demás, el espacio y el tiempo son otros, como si el pasado ya no existiera.

Para el desplazado, la partida es una ruptura con la familia, los amigos, el país, su mundo afectivo, pero, ante todo, es una derrota personal y colectiva (Rebolledo, 2001, p.2; Grinberg, 1996, p. 21). El exiliado, al dejar su tierra, reconoce que su angustia no es solo con él mismo, sino con las personas muertas o encarceladas que habían compartido sus sueños de transformar el país. Los sentimientos de culpa, provocados por el miedo y la humillación, pueden llevar a los desterrados a un estado de ansiedad y de frustración (Mercado, 1998, pp. 7-27). ¿Qué alternativas le quedan a los exiliados, más allá de desear regresar? ¿Cómo enfrentarán la vergüenza de la salida y la incertidumbre del exilio? ¿Cuáles son las representaciones más frecuentes del desarraigo y qué tipo de identidad procurará construir el exiliado durante los años que esté fuera de su lugar de origen?

Según Vásquez y Araujo (1990), la persona que está exiliada siempre piensa que está en una etapa transitoria y que su vida en el exilio será provisional, por lo que espera que ocurra rápidamente un cambio político que le permita volver (p.9). El problema es que los desterrados nunca se preparan para un exilio prolongado, se sorprenden de que las dictaduras que los expulsaron sigan en el poder, lo que choca con la idea de un exilio provisional. El efecto es devastador: «un exilio sin retorno resulta algo así como una doble derrota, como si confesásemos que aquellos que nos expulsaron lograron su cometido, cortándonos definitivamente de nuestras raíces» (Vázquez y Araujo, 1990, p. 11). Por tal motivo, los exiliados buscarán el camino del regreso, como si fueran Ulises ${ }^{4}$ moder-

\footnotetext{
${ }^{3}$ Entre algunas de las publicaciones más importantes, ver: Aguilar (1996); Kaminsky (1999); y Evangelista (1998).

${ }^{4}$ Ulises es el conocido personaje principal de La Odisea. En este mito griego, se relatan los periplos que pasó Ulises para regresar a Ítaca, su tierra natal, después de veinte años de «exilio». La ignorancia, novela de Milán Kundera, es precisamente un retrato íntimo, a partir del mito de Ulises, sobre el proceso de amnesia y de nostalgia de los exiliados checos
} 
nos, para no desaparecer de la memoria histórica, seguros de convertir el fracaso en un triunfo (Rebolledo y Acuña, 2001, pp. 3-5).

Es probable que los expatriados nunca acepten que los años de exilio fueron positivos, aunque hayan adquirido otra visión de la vida, porque el drama del destierro es impensable de otra forma que no sea dentro del mito del héroe trágico (Said, 1996, pp. 59-73; Burckas, 2005, pp. 1-2). De hecho, el tiempo del exiliado es de infortunio, de dolor, de coraje; ante las heridas abiertas el sujeto recurre, por medio de sus recuerdos escritos, a reparar los traumas de su pasado. «El exilio como destierro, dado que es vivido como injusticia, como un daño infligido, el cual debe ser reparado, fomenta la reivindicación y evita el reconocimiento de que algo está perdido para siempre» (Burckas, 2005, p. 3). Sin duda, una buena parte de los exiliados tiende a reaccionar de manera defensiva en los momentos más difíciles de su vida, ya que el tiempo vivido dentro y fuera de su tierra natal se podría perder en el olvido.

Vásquez y Araujo (1990) destacan que entre los exiliados existen ciertos rasgos comunes o etapas que distinguen las diferentes épocas del destierro. La primera etapa, la llegada al exilio, es el momento más traumático en la mente de los exiliados, ya que está cargado de fuertes sentimiento de culpa y de dolor. En la segunda y tercera etapas, los expulsados empiezan, psicológicamente, a aterrizar en el suelo adoptado, viviendo un proceso de reacomodo social y cultural en su nuevo país (pp. 23-24). ${ }^{5}$ Por último, aunque las autoras no lo proponen, consideramos que el período de retorno a su lugar de origen es importante también debido a que los exiliados pueden iniciar una reflexión más profunda de las etapas anteriores, ya que con el regreso el ex desterrado recurre a realizar un juicio ponderado de su vida, con la intención de defender o justificar su pasado de exilio, en un período histórico que considera excepcional y convulso en su vida. ${ }^{6}$

Estas etapas, por supuesto, no se pueden ajustar a todos los exiliados políticos, los cuales, por distintas razones, especialmente por la clase

\footnotetext{
${ }^{5}$ Para Mario Benedetti, el exilio tiene tres etapas: «una primera, ésa en que te negás a deshacer las maletas, porque tenés la ilusión de que el regreso será mañana. La segunda etapa es cuando empezás a interesarte en lo que sucede a tu alrededor, en lo que prometen los políticos, en lo que no cumplen, en lo que vociferan los muros, en lo que canta la gente. Sólo entonces se abre la tercera y definitiva etapa, y ahí sí empieza la comezón lujuriosa y casi absurda, el miedo a perder la bendita identidad (Benedetti, 1997, pp. 21-22)

${ }^{6}$ Para una serie de estudios sobre las experiencias de retorno en el Cono Sur, ver: Rodríguez Villaouta (1990); Sosnowski (1988) y Celedón y Opazo (1987).
} 
social, no comparten las mismas experiencias traumáticas (Cuesta Bustilla, 1999, pp. 8-10). Sin embargo, a pesar de las dificultades de estudiar cada fase del exilio, nos parece interesante analizar la memoria traumática $^{7}$ del abogado César L. Romero, utilizando como base las etapas que proponen Vásquez y Araujo (1990), aunque añadiéndole a su modelo otra etapa: el regreso. ${ }^{8}$ Contrario a otros exiliados de España y de América Latina y salvo raras excepciones, los desterrados de la República Dominicana no escribieron sus autobiografías o testimonios fuera del país, sino que esperaron hasta treinta años después de la muerte de Trujillo para empezar a publicar sus relatos del exilio (Bonilla, 2003, pp. 77102). En efecto, la producción de memorias antitrujillistas, en las que se narran las experiencias de los exiliados, no fue incorporada inmediatamente en la historia dominicana debido a que los testimonios de los ex desterrados se oponían de manera directa al discurso oficial del balaguerismo, el cual fue continuador de algunas de las prácticas autoritarias de la antigua dictadura.

Por ejemplo, el libro Del duro exilio, objeto de este artículo, fue publicado tres décadas después de la muerte de Trujillo. La memoria de Romero, quien salió de la República Dominicana en 1938, se produjo en la etapa del regreso, cuando mejor pudo llevar a cabo una retrospección e introspección de su vida como exiliado. ${ }^{9}$ Nuestra hipótesis plantea que el autor da cuenta de las diferentes etapas del exilio, remontándose a su pasado, a sus traumas, a sus ideales, a sus frustraciones, sin poder aliviar la ruptura del exilio. «La producción de este trabajo es la manera de rehacerse, de redefinirse a sí mismo, de mantener su causa y de protegerse de la humillación del fracaso y del dolor y de la incomodidad del exilio», como muy bien afirma Riddel (2000, p. 39).

En ciento ochenta y seis páginas, Romero pasa revista a los momentos más importantes de su vida, desde su infancia, antes de Trujillo,

\footnotetext{
${ }^{7}$ La memoria traumática es un término que utilizo para referirme a los trastornos de identidad política, social y cultural en las experiencias individuales y colectivas del exilio.

${ }^{8}$ Romero, nacido en la ciudad de Azua en 1909, se convirtió en un importante líder y periodista del exilio antitrujillista. Desde 1992, el autor reside en la ciudad de Murcia, España (Romero, 1989).

${ }^{9}$ Debemos aclarar que Romero, como una manera de apuntar y de limitar el contenido de su texto, entrelaza su retorno únicamente a los eventos de más repercusión política en la historia de la República Dominica en la década del sesenta. Es decir, desde su propio regreso en 1961 hasta la elección presidencial de Joaquín Balaguer en 1966, sin entrar a discutir otras etapas o sucesos de su pos-exilio antitrujillista.
} 
hasta los primeros años de la posdictadura, resumiendo cada una de las etapas que marcaron y dieron paso a su exilio. Del duro exilio es un anecdotario personal de encuentros y desencuentros con los proyectos individuales y profesionales de Romero, así como un registro autobiográfico de los componentes sociales y políticos del exilio antitrujillista. Ante la desconexión del país soñado, la recomposición de su origen cultural se vuelve una necesidad apremiante, ya que la pérdida de los elementos afectivos, como la patria y la familia, le genera una crisis de identidad social y política al autor. Son esas heridas, imágenes trenzadas por el mismo proceso del destierro, un campo fértil para poder visualizar cuáles son las estrategias discursivas que utiliza Romero para resignificar las etapas del exilio.

\section{La primera etapa: el trauma de la salida}

No es mi intención desvirtuar o menospreciar las razones que tuvieron los exiliados antitrujillistas para salir de su país, sino analizar cómo se forma o se manifiesta, en la memoria de los desterrados dominicanos, la pérdida de su espacio original, como una manera de acercarse y de señalar a los causantes de su dolor. Para César Romero, la dictadura de Trujillo provocó una ruptura traumática con los referentes sociales y políticos de su entorno cotidiano, ya que se reprimió física y mentalmente a los opositores de su gobierno (Romero, 1989, p. 13). Aparte de cuestionar a los responsables de su salida, Romero traza en los primeros capítulos una cronología del período anterior a la llegada de Trujillo al poder, la cual es fundamental para entender la problemática del sujeto que es arrojado a la experiencia del exilio. Usando como ejemplo las narraciones del pos-exilio en Argentina, Evangelista (1996) explica que la memoria autobiográfica se ubica en un «antes» y en un «después» de la dictadura y del exilio, en donde todo está relacionado con el ámbito geográfico de la infancia y la nostalgia del país desaparecido (p. 1).

El tiempo «antes» de Trujillo, según Romero, estaba lleno de ilusiones modernizadoras, de posibilidades políticas y de oportunidades económicas para el bienestar de la República Dominicana (Romero, 1989, pp. 13-14). Su niñez, en los albores del siglo XX, transcurrió rodeada de gente importante: su padrino fue gobernador de la provincia de Azua y sus tíos fueron líderes políticos de la región sur del país; asimismo, su padre dirigió un periódico conocido como El Correo del Sur. Cuando la 
intervención norteamericana terminó en 1924, la nación vivió un período de paz y de desarrollo económico sorprendente. El establecimiento de centrales azucareras, localizadas en los pueblos de San Pedro de Macorís y La Romana, así como la construcción de carreteras, escuelas y hospitales en diferentes zonas del país, generó una «euforia» de grandeza.

El autor señala que el presidente Horacio Vázquez (1924-1930), antecesor de Trujillo, fue un gobernante honesto, serio y bondadoso. En los seis años de administración de Vázquez, Santo Domingo recibió a múltiples visitantes del extranjero, incluyendo al aviador Charles Lindbergh, se realizó una exposición internacional en la ciudad de Santiago y el gobierno de Estados Unidos ayudó técnica y financieramente al Estado dominicano. Todo esto contribuyó, de acuerdo con Romero, a darle una nueva vida al país, trascurriendo esos años con mucha «felicidad». La corrupción, la violencia y el exilio empezaron con el ascenso político de Trujillo en 1930.

En el libro de Romero la escritura traumática está ligada a la pérdida y a la añoranza de los referentes espaciales y temporales resquebrajados durante el tiempo que permaneció fuera de la República Dominicana. El autor presenta un problema de identidad sobre su origen histórico debido al vacío producido por la cadena de eventos que lo alejaron de su tierra natal. Esa experiencia traumática puede implicar, por un lado, que el desterrado emprenda la tarea de escribir, deseando reconstituirse desde los recuerdos personales, como medio de reparar el daño infligido por el exilio; por otro lado, el sujeto también puede reprimir su memoria y silenciar conscientemente la información que no desea comunicar, aunque puede producir un relato alterno de su vida, utilizando la fantasía.

En su interesante libro Writing History, Writing Trauma, Dominick LaCapra (2001) advierte que el exceso de traumas propicia la construcción de imágenes «sagradas» que poco ayudan a comprender los problemas de identidad histórica, resultantes de una mala experiencia psicológica (p. 13). Por ejemplo, LaCapra señala que las culturas modernas, especialmente las occidentales, han convertido sucesos traumáticos, como el holocausto judío y la caída de las dos bombas atómicas en Hiroshima y Nagasaki, en actos subliminales debido a sus intereses políticos. El problema de la sublimidad está en la sobrevalorización «a veces peligrosa o negativa» de un trauma histórico que se transforma en un proceso incuestionable y extraordinario para algunas personas o grupos en parti- 
cular (p. 22). La gente traumatizada, por su condición, carga con una historia casi imposible de entender o de poseer, siendo muy difícil separar la realidad de la alucinación.

En el caso de Romero, la narración está signada por la pérdida de poder e influencia profesional en el escenario socio-político de la dictadura, siendo necesario, en consecuencia, idealizar el pasado antes de Trujillo. Para el autor Del duro exilio, la llegada de Trujillo al poder es producto de la «suerte», ya que la familia del tirano no tenía ninguna tradición política. En todo caso, Trujillo abusó, como jefe del Ejército, de la confianza del presidente Vázquez, que estaba viejo y enfermo, sacándolo del poder; al tiempo que expulsaba o asesinaba a los líderes políticos más importantes del país. Según Romero, no se esperaba que una persona sin valores cívicos ni morales pudiera dominar a la sociedad dominicana; por tal motivo, considera que los contactos que sostuvo, antes de salir al exilio, con los familiares de dictador lo hacían descender de clase.

A pesar de la «tragedia y la indignación» que sentía, el gobierno dominicano lo nombró cónsul en Santiago de Cuba en 1936, por lo que fue criticado rápidamente en la prensa cubana por los exiliados antitrujillistas. El autor «incómodo ante los ataques personales» reacciona:

Me vi obligado a defenderme por la misma [prensa cubana], siempre teniendo en cuenta el país y sin importarme que dijeran que yo no era abogado y otras lindezas, porque la mentira siempre se disuelve. Sin embargo, otros que no eran exiliados, pero lo aparentaban, se prestaban a servir de espías al dictador dominicano, sin llegar yo a saber quién pudo ser su conexión allí (Romero, 1989, p. 70)

Curiosamente, Romero no rompió con el régimen trujillista en 1937 por razones políticas ni humanitarias, sino por el tipo de trabajo «especial» que realizaba en el consulado. El futuro líder antitrijillista empezó a sentirse molesto y humillado debido a que se pasaba recibiendo a las amantes del presidente dominicano, poniendo, alega él, su capacidad diplomática en vergüenza. Romero, cansado de «cuidar» a las mujeres de Trujillo, decidió enviar a una de las amantes de Trujillo de regreso a Santo Domingo, sin consultarlo con el secretario del Ministerio de Relaciones Exteriores, el Lic. Julio Ortega Frier. La acción de embarcar a la concubina, de la cual Romero no dice su nombre, provocó que Ortega Frier tuviera problemas con la primera dama, María Martínez. El autor, a raíz del incidente con la amante de Trujillo, señala: 
No me destituyen abiertamente, sino que me invitaron al país para conversar. Y lo hice. Pero no conversé con nadie, ni hablé con nadie. Fui muy discreto y de seguidas con el mismo pasaporte me embarqué para Venezuela. Sin duda estaba corriendo peligro (Romero, 1989$, p. 72$)$

Aunque fue una decisión propia, Romero culpa a Trujillo de empujarlo al exilio, en el cual no fue aceptado al principio, viendo como una doble derrota su renuncia al puesto consular en Cuba en menos de un año:

No fue fácil despedirme de mi familia; nadie quería [que] me ausentara [del país] y hasta amigos oficiales del gobierno de Trujillo, pronosticaban mi porvenir como prometedor si me quedaba, no sólo por los afectos personales, sino por las muestras de laboriosidad y eficiencia en las posiciones que había desempeñado. Salir era una cosa decidida desde muchos años atrás, aunque pasare vergüenza por las cosas del país (Romero, 1989, p. 73)

Romero, en su primera etapa en el exilio (1937-1938), pensó que su posición de clase le evitaría problemas con el tirano y que podría regresar a la República Dominicana sin que fuera rechazado. Esto coincide con el planteamiento de Rebolledo (2001), quien comenta que los exiliados, desde la distancia, no pierden la esperanza de cambiar su situación, de que las cosas vuelvan a ser como eran en el pasado, que las heridas del presente se puedan sanar (p.2). La «tragedia» trujillista, como lo plantea Romero, se convierte en un drama metaforizado de las imágenes vividas en un pasado nostálgico y utópico. ${ }^{10}$ Sin embargo, cuando la vuelta al país soñado se alarga y se vuelve imposible el retorno, el exiliado sufre la pérdida más traumática de su vida: empezar a recomponer su identidad nacional desde cero.

\footnotetext{
${ }^{10}$ Por ejemplo, San Miguel (1997) arguye que la memoria y la historia son ejercicios de poder en los cuales se trata de construir «verdades» por medio de la palabra escrita. «Imaginarse el pasado como un paraíso perdido puede implicar una visión nostálgica de las clases y los sectores sociales que han perdido sus antiguos privilegios» (p. 57).
} 


\section{La segunda etapa: la permanencia traumática en el exilio}

Vásquez y Araujo (1990) argumentan que los refugiados políticos, cuando llegan por primera vez al exilio, son invadidos por sentimientos de culpa y de rechazo al país adoptado, como una forma de frenar temporalmente el proceso de transculturación que les espera ( $\mathrm{p}$. 24). El exilio se concibe como una estructura itinerante, novedosa e innovadora, que le plantea también situaciones contradictorias a los exiliados. El desterrado, en ocasiones, no desea aceptar su nueva realidad espacial, pensando que su «estadía» es provisional, se esconde incluso de los demás exiliados, evitando establecer contactos personales con otros emigrados políticos (Said, 1996, p. 63). De hecho, la integración al exilio se convierte en una situación tan compleja como la misma decisión de salir; por la tanto, la permanencia en el destierro provoca una variedad de reacciones negativas asociadas a este período del exilio.

En sus memorias, Romero recuerda que su oposición a Trujillo no ocurrió de forma inmediata, porque los exiliados dominicanos lo habían atacado duramente, siendo cónsul en Cuba en 1937. Por tal razón, viajó a Venezuela, dejando su cargo diplomático, para «alejarse» de las luchas antagónicas entre los sectores que estaban tanto en contra como a favor de Trujillo. En segundo lugar, Romero revela que pasó un año sin salir de su hogar, mientras trabajaba en una compañía de contabilidad en Caracas, evitando mantener relaciones con los exiliados antitrujillistas, y que regresó a Santo Domingo en 1938, con la esperanza de que el régimen no le recriminara su distanciamiento:

Había disimulado con mucha precisión que era desafecto, me ayudaba el haber permanecido fuera de Caracas, y por otra parte mis amigos y parte de la familia que era empleada oficial en el país, contribuía a hacer entender que no había quejas de mí. Escribí [en 1938], una carta a Trujillo en la que le significaba que yo no podía ser su enemigo personal, porque mi interés era que hiciera en el país lo que es correcto (...) y si sus amigos no lo habían ayudado en eso los debe cambiar por otros (Romero, 1989, p. 82)

Al día siguiente de enviar su carta a Trujillo, el Gobierno ordenó su arresto y encarcelamiento en la Fortaleza Ozama, antigua estructura colonial que servía como cárcel en Santo Domingo. Ante el temor de que «desapareciera», sus familiares, apelando a la propia madre de Trujillo, doña Julia Molina, lograron sacarlo con vida de la Fortaleza Ozama. 
Finalmente, después de haber estado preso por dos semanas, Romero cuenta que se ganó el repudio de amigos y vecinos, quienes temieron a las represalias de las autoridades dominicanas, ya que era considerado un «desafecto». ${ }^{11}$ Desamparado, como otros exiliados que asumieron posiciones críticas en contra de Trujillo, solicitó autorización del Gobierno para volver a trabajar en Venezuela. Estos tres sucesos antes narrados por el autor de Del duro exilio coinciden con las características más traumáticas de la segunda etapa: «la aceptación de un mundo en el que las cosas amadas ya no estarán, en que todos los contactos con él se han cortado para siempre» (Vázquez y Araujo, 1990, p. 37). Por un lado, Romero se siente culpable de no haber cambiado el rumbo político de su país; por otro lado, se niega a aceptar que los referentes de poder son otros, creando en su memoria una parálisis de sí mismo.

Ante el desarraigo cultural y el rechazo de los exiliados antitrujillistas en Cuba, Romero decidió volver a la República Dominicana, creyendo que podía recomponer el tiempo perdido, sin entender que había pasado de una respetada posición social al más cruel de los rechazos. La lógica operativa de la dictadura, no importa el país en el que aplique, es desgastar moral y físicamente a los opositores, buscando desorientar a los exiliados y a los disidentes internos por medio del temor a la muerte (Said, 1996, pp. 70-72). Durante las primeras etapas del exilio, los desterrados relatan constantemente los eventos de violencia (los secuestros, las torturas, los asesinatos) de que son víctimas los amigos o compañeros de lucha política, sintiéndose algunos de ellos culpables por no haber sufrido la misma suerte. Además, las noticias trágicas que reciben los exiliados de su lugar de nacimiento sirven para continuar hablando del «trauma» de su salida, como una manera de mantener viva la huella dolorosa de su pasado (Grinberg, 1996, p. 93).

La escritura traumática, en el caso de las memorias del exilio, está más ligada a la pérdida y a la añoranza de los referentes espaciales y temporales resquebrajados durante el tiempo que el despatriado permanece fuera de su entorno habitual. Esa experiencia traumática puede implicar que el sujeto emprenda la tarea de escribir su memoria, deseando reconstituirse desde las imágenes diluidas por el tiempo, como medio de reparar el daño infligido por el destierro. «El exilio vuelve a confrontar al sujeto con el momento traumático inaugural de la estructura don-

${ }^{11}$ Según Vega (1986), la desafección era una de las muchas categorías utilizadas durante la Era de Trujillo (1930-1961) para marcar social y políticamente a los enemigos del régimen. 
de se constituyó a partir de un vacío, que resulta ser fundante para organizar el deseo», acota Burckas (2005, p. 2). Sin embargo, no todos los exiliados tienen el «deseo» de inscribir en la memoria dichos procedimientos, reprimiendo para siempre los aspectos más angustiantes de su vida.

Este tipo de exiliado, según Vásquez y Araujo (1990), se dedica a blanquear sus faltas, culpando a los demás de no tener compromiso con las causas del exilio, como una forma de lavar sus errores personales ( $p$. 38). En cambio, para disminuir su propia culpa, el despatriado empieza un proceso de maduración psicológica, aceptando la pérdida de sus objetos afectivos, especialmente la patria y la familia, como parte de un proceso sentimental de duelo. El exiliado «renace», borra la humillación y la vergüenza de su partida, para emprender el camino de la reivindicación ante los «otros» compañeros, empezando a participar activamente en las luchas políticas del exilio (p. 39). Cuando termina siendo aceptado, el activista antidictatorial olvida sus antiguos «pecados», reconfigurando sus experiencias personales dentro del «universo simbólico» de las angustias, los fracasos y las esperanzas del destierro de su país.

Precisamente, en el caso de Romero se observa este mismo patrón psicológico, cuando regresa por segunda vez al exilio en 1938, después de intentar, por medio de una carta, que Trujillo lo perdonara. De hecho, volvió a Venezuela, en donde siguió trabajando, sin olvidar los conflictos y las luchas de poder entre los jefes del exilio. Romero recuerda:

Mi primera residencia, al regresar a Caracas, fue un antiguo hotel conocido por dominicanos, en el cual había yo vivido antes. Esta vez me encontré allí hospedado a mi antiguo maestro de la Universidad de Santo Domingo, Don Eduardo Vicioso y su esposa. Convinimos en que nunca nos entendemos, todos, o casi todos, presumiendo de líderes máximos (Romero, 1989, pp. 95-97)

Así pues, aprovechó su condición de ex trujillista para criticar que las diferentes agrupaciones de exiliados en Cuba, México, Venezuela, Puerto Rico y Nueva York distaban mucho de estar unidas por un mismo ideal. Por ejemplo, Romero señala que las reuniones de los exiliados servían para que cada uno de ellos atacara o acusara a otros compañeros de no cooperar con las actividades antitrujillistas. El autor comenta que llegó hasta a defender la reputación de figuras relevantes del exilio dominicano, como el Dr. Luis Felipe Mejía, quien fue acusado de «traidor» 
por los hermanos Félix Servio y Juan Ducoudray, ya que ambos seguían una línea más dogmática en torno a los asuntos del destierro antitrujillista. ${ }^{12}$ En adición, Romero recuerda que las rivalidades políticas entre los líderes dominicanos por el control de las facciones en el exilio afectaron siempre los planes para derrocar a Trujillo. En cambio, destaca que fue su capacidad de zanjar controversias la que permitió sus primeros acercamientos personales, en la década del cuarenta del siglo pasado, con los exiliados antitrujillistas en Venezuela.

Capaz de vencer cualquier obstáculo, según él, restableció contactos con amigos y conocidos, quienes empezaron a valorar su disposición a dialogar y a colaborar en las necesidades del exilio. El autor de Del Duro exilio considera que fue su «sensibilidad»social la que permitió convencer a los líderes dominicanos de que podía cooperar con la causa antidictatorial: «[En Caracas] se me ocurrió promover una agrupación para recabar fondos y lograr cierta acción que era indispensable. Se trataba de una organización tipo mesa redonda donde cada uno era Jefe. No tuve éxito» (Romero, 1989, p. 96).

Sin embargo, Romero aclara que la comunidad dominicana en Venezuela fue la más fraternal entre las agrupaciones antritrujillistas en América Latina y el Caribe, y que mostró la misma disponibilidad de lucha que los exiliados en Cuba, a pesar de que contaba con menos recursos económicos:

La diferencia [entre los exiliados de Caracas] y los compañeros de La Habana consistía en que éstos, económica y personalmente, se ayudaban porque su dinámica única o principal era la lucha en contra del dictador. Los de Venezuela no dedicaban todo su tiempo a ello. Aunque no debe dejar de decirse que en los momentos de prueba nadie se quedaba rezagado, ni los que presumían de extrema izquierda (Romero, 1989, p. 99)

En esta segunda etapa del exilio, de acuerdo con Vásquez y Araujo (1990), el exiliado se dedica a trabajar intensamente, no se permite ninguna debilidad, ya que su comportamiento ante la comunidad expatriada debe ser ejemplar (pp. 39-40). El líder o el militante se avergüenza de haberse salvado, poniendo todas sus energías en no olvidar a los muer-

\footnotetext{
${ }^{12}$ Sin embargo, en sus anecdotarios sobre las experiencias del exilio antitrujillista, Ducoudray (2000) no menciona este incidente con el Dr. Luis Felipe Mejía.
} 
tos de la dictadura. De acuerdo con LaCapra (2001), las «deudas con los muertos» crean en los sujetos un deseo inconsciente de permanencia dentro de la condición traumática, generando así resistencias o inmovilidades para resolver sus propios problemas de sufrimiento (pp. 22-23). El exiliado resalta en su memoria las limitaciones económicas en las que desarrolló su vida fuera de su patria para justificar sus principios morales.

Según Vásquez y Araujo (1990): «el exiliado se siente culpable cuando goza de una migaja de felicidad, cuando no comparte la desgracia de su país» (p. 40). El desterrado, con esta actitud desea demostrar que su exilio fue incómodo, agotador y, sobre todo, peligroso, para no dejar duda de su lealtad incondicional con la «causa». Por tal motivo, como una manera de pagar su culpa, el exiliado está constantemente señalando los riesgos de su militancia, por lo que en sus relatos no pueden faltar las traiciones, las persecuciones y los asesinatos de otros compañeros en el extranjero. El «yo» que diseña la memoria, dice Olney (1972), tiende concientemente a mover los eventos a la (in)discreción de los recuerdos, creando un nuevo orden de emociones y de valores en su vida (p. 27).

Efectivamente, en la segunda parte de su libro, Romero destaca su reconstrucción social como exiliado dominicano, aceptando la condición de desarraigo, para así curar sus heridas e integrarse de lleno a la comunidad refugiada. Además, en esta etapa de permanencia, el autor de $\mathrm{Del}$ duro exilio descubre su «vocación», su liderato político, poniendo sus talentos a la disposición de los demás miembros del exilio antitrujillista. Por ejemplo, en la década del cincuenta, Romero desarrolló una importante labor periodística en contra de Trujillo, aportando recursos propios para desarrollar una campaña de información en torno a los crímenes políticos en Santo Domingo. A raíz de la muerte del periodista Andrés Requena, ${ }^{13}$ editor del mensuario antitrujillista Patria, Romero se ganó la «confianza» de los principales líderes del exilio, como Juan Isidro Jimenes Grullón, Leovigildo Cuello y Ángel Morales, quienes le encargaron continuar la redacción y la distribución del periódico en Estados Unidos.

\footnotetext{
${ }^{13}$ En 1952, Trujillo ordenó el asesinato de Requena, quien había escrito, en 1949, una novela titulada Cementerio sin cruces, siendo víctima de los funcionarios consulares del tirano en Nueva York, los cuales, intentando silenciar sus críticas al dictador, planificaron su muerte (Céspedes, 2001, pp. 11-17).
} 
En la capital norteamericana, Romero pasó rápidamente del anonimato al protagonismo en las luchas del destierro dominicano, participando en diferentes protestas frente a la Casa Blanca, el Congreso y el Departamento de Estado. Pero el día más duro de su vida como exiliado fue cuando observó, en la capital estadounidense, a cientos de personas, pagadas por la Embajada dominicana, saludando a Trujillo, mientras el grupo en contra del tirano caribeño no superaba las 200 personas:

Cuando vi, cerca de las 12 del día, desfilar frente al hotel Mayflower a Trujillo, saludando desde el balcón a una multitud que parecía de más de mil personas con profusión de banderas dominicanas y bailando al son de merengue, confieso que sentí deseos de llorar. Ningún otro día había sido más amargo en mi exilio. Conocí a muchos a quienes nunca presumí que podían ser tan abyectos (Romero, 1989, pp. 126-127)

En los últimos años de la dictadura, el régimen trujillista incrementó la persecución en contra de los exiliados dominicanos, vigilando estrechamente sus actividades opositoras. En la década de los cincuenta, resonaron los casos del líder obrero Mauricio Báez, asesinado en Cuba, la ejecución de Sergio Bencosme, en la puerta de su apartamento en Nueva York, y las muertes de dos reconocidos intelectuales españoles, Jesús Galíndez y José Almoina, exterminados por escribir sendas obras en contra de la dictadura de Trujillo. Estos casos, alega Romero, repercutieron en la imaginación de los sectores antitrujillistas en el exilio, ya que los agentes diplomáticos del tirano asechaban a los desterrados dominicanos en sus lugares de trabajo y en sus propias residencias. El autor narra su experiencia:

Siempre anduve muy precavido en la calle, como cualquiera que sepa que lo persiguen y no para nada bueno. Cuando iba a buscar mi carro, siempre lo hacía en el momento que también otros del periódico iban hacia el mismo lugar y con el mismo propósito. Noté a la mitad del trayecto que me venían siguiendo en otro automóvil que no podía distinguir. No lo perdí de vista y mantuve mi arma preparada cerca de mi mano derecha. Cuando indagué en la institución de seguridad, me informaron que la placa del auto correspondía a Enrique de Marchena, ministro consejero de la Embajada Dominicana en Washington (Romero, 1989, pp. 130-132) 
El sistema de inteligencia trujillista era tan eficiente que no dejaba pasar desapercibida la mudanza o la llegada de algún enemigo del régimen a los centros más importante del exilio en Estados Unidos y en América Latina. Por tal motivo, Romero lamenta que algunos dominicanos se mantuvieran alejados de las agrupaciones de exiliados, optando por una vida más tranquila y cómoda en otras ciudades de Estados Unidos y de América Latina. ${ }^{14}$

El autor de Del duro exilio, como puede observarse, sigue una estrategia de narrar las pérdidas colectivas, resaltando los sufrimientos, los sacrificios y los riesgos de los desterrados, para buscar la compresión y el apoyo de los demás expulsados. Contrario a la primera etapa de su destierro, marcada por el duelo individual, en esta segunda etapa Romero se encuentra en la necesidad de refugiarse en las actividades antitrujillistas como una manera de generalizar y de compartir la culpa del exilio. No obstante, la militancia activa puede provocar entre los exiliados reacciones exageradas, producto de la inestabilidad emocional, llegando a sentir desconfianza de sus propios compañeros. Según Vásquez y Araujo (1990), «los exiliados temen que los sigan en la calle, se les ocurre que cualquier extranjero en la comunidad es un agente enemigo, desconfían también de los compatriotas que no son refugiados» (p. 42). Por ejemplo, en una ocasión, Romero recuerda haber recibido la llamada de una persona alegando ser recomendada por el Dr. Cotubanamá Enríquez, quien era un importante líder del exilio en La Habana, ya que deseaba entrevistarse con él para participar en las actividades en contra de Trujillo en Estados Unidos:

Me estremecí cuando me vino a la mente que [la reunión] podía ser un plan macabro de Trujillo para liquidarme. Siempre creí en todas las posibilidades desde que estaba de cónsul en Santiago de Cuba, cuando más de un «exiliado» se me ofreció de espía (Romero, 1989, p. 116)

De hecho, el autor señala que llegó a sospechar de parientes y de amigos, quienes mantuvieron en secreto su trabajo como agentes del régimen trujillista, mientras se hacían pasar por compañeros del exilio. Romero, después de la muerte de Trujillo en 1961, comprobó que varios

\footnotetext{
${ }^{14}$ De hecho, una parte de ellos no volvió a participar en actividades antitrujillistas ni retornaron, después de la muerte de Trujillo en 1961, a la República Dominicana.
} 
supuestos desterrados antitrujillistas «de los cuales no dice sus nombres» eran pagados por los servicios diplomáticos del gobierno dominicano.

Finalmente, Romero carga con la ilusión de regresar, de contar cómo sobrevivió a los peligros del exilio, estableciendo así las condiciones de posibilidad de su narración. El autor, como parte de su aprendizaje, intenta cultivar una imagen de realización de su persona, sintiendo un compromiso político con el destino de su país. Pero el desterrado tiende a negar el presente que vive en el extranjero, sin comprender el porqué de la dictadura, aflorando las mismas divisiones sociales e ideológicas que existían antes de salir de su patria. Será con la permanencia en el exilio que cada uno de los exiliados podrá dibujar sus traumas en la memoria.

\section{La última etapa: el trauma del retorno}

Si la salida hacia el exilio es recordada como un proceso doloroso y traumático, para algunos exiliados antitrujillitas más difícil resultó el añorado regreso, a partir de 1961. El sueño de la mayoría de los exiliados es volver a su país de origen, reencontrarse con el espacio perdido, vincularse con los mismos códigos y objetos dejados tras su salida, como si el tiempo no hubiese pasado por ellos (Rebolledo, 2004, p. 2). Mas, cuando se regresa, el ex desterrado se encuentra confundido al no poderse vincular con los mismos referentes cotidianos de su pasado, percatándose de que su mundo idealizado, tanto social como político, le fue arrebatado. Parte del problema estriba, según Aguilar (1996), en que al exiliado le resulta chocante y angustioso no verse reconocido por las demás personas, sintiendo que su proyecto personal fracasó y que su vida no tiene importancia para los distintos componentes de la sociedad (p. 38).

Esto provoca que el retorno sea percibido como una nueva pérdida traumática, debiendo los exiliados empezar su readaptación espacial y temporal desde cero. El escritor Mario Benedetti, en el artículo que da nombre a su libro, inventa un término bien interesante para referirse al proceso de regreso de los desterrados políticos a sus países de orígenes: el desexilio. El, quien habla por experiencia propia, ya que pasó once años (1973-1984) fuera de su país, Uruguay, motivado por un golpe de Estado, señala que el desexilio puede ser tan arduo y tan complejo como el mismo destierro debido a las actitudes entre los exiliados, al intentar forzar su acomodo o restitución en el territorio que abandonaron, sin 
comprender los cambios ocurridos en su sociedad de origen durante los años que estuvieron refugiados en el extranjero De acuerdo con el autor de El olvido está lleno de memorias, es fácil caer en la tentación de reprocharse y de desentenderse unos de otros, entre los que se quedaron y los que salieron, llegando «a ser una herencia maldita que sólo serviría para enrarecer el futuro» (Benedetti, 1984, pp. 39-40).

De hecho, en su última etapa, el desexiliado pasa por un proceso de adaptación, buscando el mundo que dejó, mostrándose extraño e inconforme con las nuevas condiciones sociales y políticas de su país. ${ }^{15} \mathrm{El}$ ex desterrado tiene que enfrentarse al espacio perdido, a las amistades dejadas, a su propia fragmentación, para unir las piezas quebradas por el exilio. El exiliado, argumenta Evangelista (1998), emprende el camino de la memoria intentando comprender las nuevas realidades políticas de su país, buscando «curar» las heridas del desarraigo a través de la rearticulación con sus «objetos perdidos». De esta forma, el sujeto exiliado narra con la intención de reafirmar sus valores morales, de denunciar a los «otros» que provocaron su salida, los cuales son responsables de su transfiguración cultural y de su desplazamiento en el tiempo y el espacio (p. 3).

El trabajo de la memoria, a nuestro modo de ver, empieza a funcionar cuando el pasado y el presente pasan a una dimensión incompresible para el testimoniante, viendo cómo su vida nunca termina por resolverse. De hecho, las contradicciones existentes en las formas de recordar u olvidar, después de la muerte de Trujillo, llevaron a los exiliados de la República Dominicana a asumir una visión antagónica sobre su relación con la memoria política del país. Entre los desterrados antitrujillistas fue patente el resquebrajamiento y el alejamiento temporal y espacial de los sucesos que desencadenaron la eliminación física de Trujillo. El regreso de los dominicanos del exilio no se dio gracias a las «heroicas» acciones de los desterrados, sino debido a una conspiración interna en la que participaron varios de los seguidores del dictador, quienes lo ajusticiaron en una de las avenidas de Santo Domingo.

La novedad extraña del «país perdido», que se recupera sin la participación directa de los exiliados, los devuelve a la imagen de fragmentación del pasado, sintiendo el antiguo desterrado que su vida en el exilio

\footnotetext{
${ }^{15}$ Según Mercado (1998): «cuando se piensa que el exiliado regresa a su tierra y es recibido por esa madre que malamente lo desterró, se tiene una idea por lo general errónea acerca de la índole del mercadrecibimiento: no hay norma que prescriba la bienvenida, y si ésta se expresara como un buen deseo al regresante, sólo sería una formalidad» (p.85).
} 
pasó sin pena ni gloria. Pero como el dolor y el sufrimiento no terminan hasta que la víctima no muere, el exiliado buscará reparar, por medio de la palabra escrita, la «verdad» de su historia: ese recuento personal, rebosante de experiencias traumáticas y nostálgicas que lo elevan subjetivamente «en el ámbito ético» sobre los demás mortales. La memoria traumática no solo aspira a condenar las etapas del destierro, sino también mueve a los «afectados» a recordarle a su comunidad lo que continúa vigente de «ese» pasado en el presente. «El pasado no es sólo tiempo pretérito sino, también, actualidad que se manifiesta de manera compleja a través de la memoria», como muy bien indica Elgueta (2000, p. 33).

De todas las etapas vividas por Romero en el exilio, la última (la del retorno a la República Dominicana) es la más «dura» que le resulta detallar, siendo la menos informativa de su memoria, aunque produce un relato alterno y revelador de su vida, usando su experiencia personal:

Hoy sufrimos el profundo atraso de nuestro pueblo, porque hasta ahora no se ha atacado el mal [de la antigua dictadura trujillista] por culpa de gobiernos ineptos e incalificados. Pero es [de] esperarse que en algún futuro próximo todo ello cambie y que se tenga la verdadera conciencia del estado actual de nuestro [país], para lograr el principio del desarrollo, la educación y la moral (Romero, 1989, p. 164)

Romero, contrario a lo que había enfatizado anteriormente, confiesa ahora que los años de desarraigo en Estados Unidos fueron de profundo crecimiento intelectual y social, guardando los «mejores» recuerdos de su extenso itinerario profesional. «En el exilio nunca pasé mejores tiempos que aquellos transcurridos con gente culta que inspiraban y contagiaban su interés por la superación de la humanidad en los diversos campos», afirma Romero (1989, p. 173).

Por supuesto, el autor de Del duro exilio cae fácilmente en la trampa de la nostalgia exagerada, exponiéndose a la invención de su propia realidad, para sentirse menos culpable y sacarle provecho a su antigua condición de refugiado político. El problema que esboza Romero es en parte uno de clase debido a que, a su regreso al país estaba muy dolido por la exclusión política de la burguesía dominicana, la que esperaba «heredar» nuevamente el poder en 1961. De hecho, Romero no se explica cómo la Unión Cívica Nacional (UCN) ${ }^{16}$ perdió las elecciones en 1962

${ }^{16} \mathrm{La}$ UCN se formó en 1961 como una agrupación «apolítica y patriótica», teniendo 
ante un líder desconocido en la República Dominicana, como Juan Bosch. Según él, la UCN encarnaba los verdaderos valores de la lucha «titánica» en contra de los remanentes del trujillismo:

La saturación y el endiosamiento [trujillista] hizo que las mentes de casi todos los dominicanos de alguna significación se hayan quedado acomplejados por el hecho de no poder disentir o no tener cara para poder disentir de un régimen que aplaudieron todo el tiempo y les dio de comer, sin importar crímenes y la barbarie más absoluta. La obra del Dr. Viriato Fiallo de crear un partido de gran repercusión social y luchar contra la corriente fue una obra titánica. Esa masa, residuo del trujillismo, se volcó en favor de Juan Bosch a quien no odiaban tanto (Romero, 1989, p. 176)

Esta declaración resulta interesante porque Romero y Bosch eran amigos personales, habiendo militado juntos en el exilio antitrujillista por más de veinte años. Sin embargo, como muy bien explica Radley (1992), cada clase social reproduce un tipo particular de recuerdo, así que «el sentido de su historia viene determinado por la capacidad para guiar su propia vida y llevar a cabo su paso por las dificultades económicas y físicas de su entorno» (p. 66). La posición de Romero refleja una profunda crisis de identidad de los mitos que constituían al exilio antitrujillista, ya que la imagen de unidad y de solidaridad entre ellos se desmoronó mientras más se acercaba la fecha del regreso. Los exiliados, con el tiempo, preparan a su conveniencia su retorno, así que los grupos o las organizaciones políticas fuera del país funcionan de acuerdo con sus propios intereses ideológicos y sociales sin medir el daño que pueden provocar en su comunidad (Vázquez y Araujo, 1990, p. 68).

Por ejemplo, el autor expone que los intentos de invadir militarmente a la República Dominicana, en 1959, provocaron profundas divisiones políticas entre los exiliados antitrujillistas. ${ }^{17}$ Por un lado, según Romero, los miembros del Partido Revolucionario Dominicano querían tener su propio frente militar, lo cual ocasionó que uno de los principales

como líder al Dr. Viriato Fiallo, quien se ganó la admiración de los sectores más progresistas de la sociedad dominicana por sus posturas antitrujillistas.

${ }^{17} \mathrm{El}$ primer ataque aéreo se realizó por el pueblo de Constanza, localizado en la parte central de la República Dominicana, el 14 de junio de 1959. La segunda expedición militar fue un desembarco por las playas de Maimón y Estero Hondo, entre el 15 y el 20 de junio, en la costa norte del país. De las dos invasiones, solo sobrevivieron seis personas, dos cubanos y cuatro dominicanos, de un total de 195 combatientes. 
líderes de la expedición de Constanza, Maimón y Estero, el comandante Enrique Jiménez Moya, objetara dicha propuesta; por otro lado, el autor lamenta que la falta de preparación militar de los exiliados antitrujillista provocara la pérdida de vida entre la juventud dominicana. «Nunca hubo identificación de unidad completa en todos los grupos de dominicanos [que participaron en las expediciones de 1959], específicamente por complejidades de categorías en los mandos y finalmente la responsabilidad de la tarea quedó en las manos del grupo afín a Jiménez Moya», afirma Romero (1989, p. 167).

En el exilio, son más comunes los ataques, las contradicciones y las omisiones que los puntos de coincidencia, reconocimiento y apertura entre los miembros del destierro antidictatorial. Además, cuando el proyecto personal fracasa, al no poder ser parte de la transición política, y deseando con el regreso superar el estado de anomía, su visión social e histórica se torna «trágica». De acuerdo con Romero, Bosch, quien había sido una importante figura del exilio, separó o eliminó a los «verdaderos» representantes de la sociedad dominicana, quedando aislado del apoyo político de sus propios seguidores, hasta que ocurrió el golpe de Estado de 1963. Para el autor de Del duro exilio, los eventos que se desencadenaron después de la salida de Bosch del poder, fueron tan tristes y duros como los años de exilio antitrujillista: «He venido a pensar que el trauma físico [del exilio] fue tan grande como el trauma moral y social realizado por los herederos de Trujillo al cercenar la oportunidad democrática, al inicio del nuevo orden después del ajusticiamiento del tirano (Romero, 1989, p. 171).

En primer lugar, Romero lamenta que los líderes de la UCN apoyaran la formación de un triunvirato: el gobierno ilegal impuesto por los militares golpistas. En segundo lugar, para desligarse de lo sucedido, afirma que gastó sus ahorros personales en boletos de avión, intentando ayudar a los líderes políticos que fueron exiliados por el triunvirato, buscando soluciones a la crisis institucional en Santo Domingo desde 1963 hasta 1965. Por último, recuerda con nostalgia los tiempos de lucha en contra de Trujillo, cuando el enemigo era solo uno, mientras que ahora la República Dominicana estaba en manos de «30 caballeros», en alusión a los sectores golpistas del país, los cuales eran muy difíciles de entender o descifrar.

A pesar de participar en la «reconciliación» democrática en Santo Domingo, es decir en los intentos de reponer a Bosch en el poder, Romero vuelve a repetir los sentimientos de culpa y de vergüenza, como si 
estuviera viviendo todavía en la Era de Trujillo. El autor tuvo que regresar de nuevo a su antiguo exilio en Estados Unidos, ya que no se sintió «apreciado y valorado» por el pueblo dominicano. Romero, quien fue profesor universitario en la ciudad de South Bend, Indiana, en 1963, confiesa:

En todo el tiempo de mi largo exilio, nunca me sentí tan a gusto como siendo maestro de jóvenes agradables y de finas maneras. Así como al mismo tiempo poder disfrutar de muchas actividades culturales, sin dejar de significar que encontré a todo el mundo interesado en lo que sucedía en nuestra isla caribeña (Romero, 1989, p. 172)

Como un «noble» maestro, apegado a las cuestiones políticas y culturales de la República Dominicana, Romero puede justificar su permanencia y bienestar en el exilio, aliviando también su culpa, ya que siempre vive en la tónica del «largo» destierro. Finalmente, el autor, quien escribe casi tres décadas después de terminada la tiranía, sigue «asombrado» de que los héroes y los participantes del exilio antitrujillista no hayan retomado su espacio, su destino, en las luchas políticas del presente. Pero las memorias de sufrimientos, sacrificios y traumas son metáforas discursivas que crean más interrogantes que posibles soluciones a los problemas del exilio. En efecto, como la última etapa no resolvió el trauma inicial, Romero continúa anclado en los mismos problemas de identidad social y política que tenía cuando salió por primera vez hacia el exilio. De hecho, el tema de la dictadura de Trujillo está presente en la memoria de Romero, como si fuera un estado de vigilia permanente, para recordarle a los lectores que los traumas de su destierro están muy lejos de haber sido clausurados.

El autor de Del duro exilio continuó «sangrando» por la herida del regreso sin poder entender su propia condición de desterrado. Es decir: su malestar e inseguridad se deben al desconcierto en torno al tiempo «indefinido», por lo que su vida nunca termina de resolverse y el sueño de retornar triunfalmente a su país se perdió para siempre. Su vida, truncada por el dolor y la humillación del exilio, representó una «maldición», ya que se sintió tan extranjero en su propio territorio como el mismo Ulises, que después de veinte años no podía entender por qué su pueblo no lo reconocía. Ante las injusticias del olvido, Romero construye su propia «vOZ» de autoridad, reordena su mundo despedazado con la ilusión y la esperanza de reinsertarse por derecho propio en la historia de 
su país. Pero al no lograr su cometido, el autor se siente abatido e incómodo con los «otros» que no lo escuchan, mostrando en la memoria escrita los traumas más evidentes del regreso: su falta de comprensión de las diferentes etapas del exilio.

\section{Referencias}

Aguilar, P. (1996). Memoria y olvido de la Guerra Civil española. Madrid: Alianza Editorial.

Alonso, C. (2000). El exilio hecho escritura: Aprender en la errancia. Enrahonar, (31), 124-134.

Andrés, B. (2002). Exilio, memoria, identidad. En: C. Godoy (Comp.), Historiografía y memoria colectiva (pp. 83-89). Buenos Aires: Miño y Dávila.

Benedetti, M. (1984). El desexilio y otras conjeturas. Madrid: Ediciones El País.

Benedetti, M. (1997). Andamios. México: Alfaguara.

Bonilla, W. (2003). Entre el recuerdo y el olvido: Las memorias de los exiliados antitrujillistas. Revista Mexicana del Caribe, (15), pp. 77103.

Burckas, C. (2005). Escribir el exilio-hacia el lugar de la falta en el Otro. Disponible electrónicamente en http://www.freud-lacan.com/ index.php/fr/actualite-des-travaux-de-1-ali-blog/44-categories-fr/ site $/ 587$

Celedón, M. y Opazo, L. (1987). Volver a empezar. Santiago: Pehuén.

Céspedes, D. (2001). Camino de fuego y Cementario sin cruces. Santo Domingo: Ediciones Ferilibro.

Cuesta Bustillo, J. (Ed.). (1999). Retornos: De exilios y migraciones. Madrid: Fundación Francisco Largo Caballer.

Ducoudray, J. (2000). Réquiem por la utopía y otras saudades. Santo Domingo: Editora Nomara.

Elgueta, G. (2000). Politicas y estéticas de la memoria. Chile: Editorial Cuarto Propio.

Evangelista, L. (1998). Voices of the Survivors: Testimony, Mourning and Memory (Argentina 1983 1995). New York: Garland Publishing. 
Grinberg, L. y Grinberg, R. (1996). Migración y exilio: Estudio psicoanalítico. Madrid: Editorial Biblioteca Nueva.

Guinsberg, E. (2005). Migraciones, exilios y traumas síquicos. Politica y cultura, (23), pp. 161-180.

LaCapra, D. (2001), Writing History, Writing Trauma. Baltimore: The Johns Hopkins University Press.

Mercado, T. 1998). En estado de memoria. Córdoba: Alción.

Olney, J. (1972). Metaphors of Self: The Meaning of Autobiography. Princeton: Princeton University Press.

Kaminsky, A. (1999). After Exile: Writing the Latin American Diaspora. Minneapolis: University of Minnesota Press.

Rocha, C. (2003). Violencia de Estado y literatura en Argentina (19732003). Amnis, (3), pp. 193-211.

Radley, A. (1992). Artefactos, memoria y sentido del pasado. En: D. Middleton y D. Edwards (Eds.). Memoria compartida: La naturaleza social del recuerdo y del olvido. Barcelona: Ediciones Paidós.

Rebolledo, L. (2004). Volver del exilio. Revista Rocinante Digital, (64).

Rebolledo, L. (2001). Exilio y memoria: De culpas y vergüenzas. Ponencia en el Cuarto Congreso Chileno de Antropologia, Universidad de Chile.

Rebolledo, L. y Acuña, M. (2001). Narrativa del exilio chileno. Anales, Nueva época, (3-4), 3-20.

Riddel, M. (2000). Última etapa del exilio de María Teresa León: La escritura reparadora. Donaire, (14).

Rodríguez Villaouta, M. (1990). Ya nunca me verás como vieras. Santiago: Ediciones de Ornitorrinco.

Romero, C. (1989). Del duro exilio. Santo Domingo: Impresora Valdez.

Said, E. (1996). Representaciones del intelectual, traducción de Isidro Arias. Barcelona: Ediciones Paidós.

San Miguel, P. (1997). La isla imaginada: Historia, identidad y utopia en La Española. San Juan/Santo Domingo: Isla Negra/La Trinitaria.

Sosnowski, S. (1988). Represión y reconstrucción de una cultura: El caso argentino. Buenos Aires: Editorial Universitaria de Buenos Aires.

Vásquez, A. y Araujo, A. (1990). La maldición de Ulises: Repercusiones psicológicas del exilio. Santiago: Editorial Sudamericana. 
Vega, B. (1986). Unos desafectos y otros en desgracia: Sufrimientos en la dictadura de Trujillo. Santo Domingo: Fundación Cultural Dominicana. 